\title{
RESTORATION WORKS DETERMINANTS OF COMPLETIONS IN MAMLUK PALACES CASE STUDY: PALACE OF PRINCE TAZ
}

\author{
Badawi Mohamed ISMAIL ${ }^{1, *}$, Yasmine Sabry HEGAZI ${ }^{2}$
}

${ }^{1}$ Conservation Department, Faculty of Archaeology, Luxor University, Egypt

${ }^{2}$ Architecture Department, Faculty of Engineering, Zagazig University, Egypt

\begin{abstract}
Several international conventions and charters which issued by ICOMOS reviewed the idea of completion historic buildings. Some supported the absolute thought of completion and the need to adapt it as one of the necessities of conservation operations, so as to put the fingerprint of current modern technologies on restoration and preservation processes while others went to keep this process at the minimum intervention level. With using the original materials at the restoration process, this paper highlighted charters and conventions contribution to the idea of completion. research problem pointed to the close connection between the completion and the authenticity regarding the decisions of restoration of the historic buildings, This was discussed by examining the status of the restoration of Prince Taz Palace project, which occurred in a partial collapse made an alarm to start the restoration work and resulted set of decisions related to the idea of completion, which has developed its philosophy according to the changing cases that appeared in the palace, and also the completion works varied not only at the level of intervention, but also at its kinds as structural, architectural and fine art elements, The study focused on the descriptive methodology and analytical approach through the selected case study. The research concluded that the philosophy of completion varies according to each case. And one building can include several levels of completion provided that there are archaeological and documentary evidence to prove this.

Keywords

Palace of Prince Taz, Completions, Charters, Conservation, Restoration.
\end{abstract}

\section{Introduction}

The Egyptian lands are full of many historic buildings that resulted from the interaction of successive civilizations on their land. Those buildings have been exposed to many natural and human hazards which have caused a severe deterioration over the years, many of which have suffered from its age which might be hundreds of years or even thousands of years. As The buildings of the ancient Egyptian architecture, which have been resistant to the various burdens of deterioration.

1992 earthquake alerted Egypt to the deteriorated status of those monuments, particularly the Islamic monuments of historic Cairo, which revealed the extent of its poor condition and its bad need for urgent action to preserve an Egyptian civilization that reflects a rich period of time, we have had important monuments, that at the Mamluk rule of Egypt, where the buildings and the palaces reflected different layers of social and financial, which left a variety of Islamic architecture, including the Mamluk palaces, which left buildings not many and most of them incomplete, due to the carelessness of the Ottoman era, Ottoman came to Egypt after The rule of the Mamluks.

\footnotetext{
*Corresponding author: badawi_16@yahoo.com
} 
Palace of prince Taz is one of the most complete Mamluk palaces inhabited by one of the princes. Its rich architecture reflected the greatness of its owner and its almost complete architectural elements reflected the design basics of Mamluk architecture at that time. It has been used for many uses, including storages for the Ministry of Education, which caused deterioration to its construction.

until the collapse of the mass of the HaramLk (women residence) happened upon Sheck Khalil Alley, which is facing the background elevation of the palace, urgent intervention had been taken to preserve the humans and the historic building, and here a restoration project began, this project included several Decisions concerning the completion of variable elements each have its own philosophy which discussed through this research.

\section{Case Study: Prince Taz Palace:}

The founder is Prince Saif al-Din Taz ibn Qatgaj, one of the prominent princes in the era of the Mamluk, whose star began to ascend during the rule of Saleh Ismail Ibn al-Nasir Muhammad (743-746 AH / 1343-1345 AD) until he became one of his princes (758 AH-1351 AD). The palace, after the death of its founder, became a residence for "others until it was destroyed and transformed to a storage of war equipment at the time of Muhammad Ali and then a school for girls (Al-Helmiya secondary school) and a primary school which he ordered to transfer its name to the school of Khedive Ismail (1308 AH-1871).

After that, the ownership after that belonged to the Ministry of Awqaf and turned into storages of the Ministry of Education and then began the stages of restoration due to the severe deterioration, which was severely affected" by the earthquake of October 1992.

The palace considers one of the special Mamluk palaces, due to the completion of most of the architectural elements that reflect the great design of Mamluk architecture in Egypt during this period. The palace was located on Siyofiya Street and had a long history of unsuitable use. It was used as a school and then as a storage for the Ministry of Education. This caused pressure and excessive loads on the walls and slabs of the school objects weights, In addition to the factors of time and non-restoration for long periods, as well as some of the incorrect repairs that were made in previous eras, all of which led to the deterioration of the state of the building and the occurrence of partial falls; were the main reason for the start of the restoration project.

\section{Structural Completions:}

Due to the partial collapse of the building, a completion of a middle mass was necessary to join two masses, that joining action prevented the movement of the masses which achieved structural safety and restored the visual image as well. 


\section{Architectural Completions:}

The process of architectural completions is one of the most difficult decisions to be made. The degree of necessity is reduced to be less degree than the structural completions, as that structural completion can prevent the loss of part of the building or prevent the movement of the walls. The architectural works mostly about form and might be major or minor, The difficulty of understanding the architectural form without the completion process, mostly govern the completion decision.

\section{Fine Art Elements Completions:}

most difficult than structural and the architectural completion, because it is difficult to distinguish the completion of the original and the additions to the element after a period, especially in the work of ornaments restoration, as it passes several years and colors become close in degrees to the original, and that can only be seen from close distance. Due to ceiling huge height.

\section{Conculsion:}

The lower the process of completions, the more monument authenticity achieved, so the completion should be kept in the minimum level, and in cases of extreme necessity, which are gradually allowed from top to bottom, where the top is the acts of structural necessity, and then the elements that are weak bonding around them such as the plaster, The study recommends that each case of completion should be treated individually and according to studies, documents and all archaeological evidence that support or exclude the process of Complement.

\section{References:}

- Mohammed Hefny MOGHAZY, Nagwa Sayed ABDEL RAHIM, Hamdy Abdel Moniem MOHAMMED, Rasha Taha ABBAS, AN APPLIED STUDY FOR THE RESTORATION OF A GLASS LANTERN DAMAGED BY THE EXPLOSION AT THE MUSEUM OF ISLAMIC ART IN CAIRO, International Journal of Advanced Studies in World Archaeology, Vol. 1, No. 1, 2018, pp. 7-9.

- Reda Farag ISMAIL, RESTORATION OF RUQYAH COVERS (MANUSCRIPT OF KITAB AL-TIBB BY IBN SINA), International Journal of Advanced Studies in World Archaeology, Vol. 1, No. 1, 2018, pp. 10-15. 